The Israeli Journal of Aquaculture IJA.73.2021.1490779, 9 pages

CCBY-NC-ND-4.0 • https://doi .org/10.46989/001c.27636

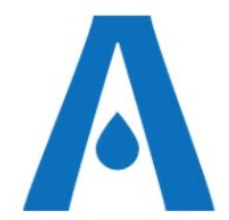

The $I J A$ is a peer-reviewed open-access, electronic journal, freely available without charge to users

Produced by the AquacultureHub non-profit Foundation Sale of IJA papers is strictly forbidden

\title{
Status, Trends, and Prospects of the Channel Catfish Industry in China and the impact of the Covid-19 epidemic
}

\author{
Zhen Zhou ${ }^{1 \#, ~ Y u n-Y u n ~ D a i 2 \#, ~ Y u a n ~ Y u a n ~}{ }^{3 *}$, Yan-Hui He ${ }^{3}$ Jing Zhou \\ ${ }^{1}$ Business and Finance School, Wuxi City College of Vocational Technology, Wuxi \\ 214081, China \\ ${ }^{2}$ School of Management, Wuxi Institute of Technology, Wuxi 214121, China \\ ${ }^{3}$ Key Laboratory of Freshwater Fisheries and Germplasm Resources Utilization, Ministry \\ of Agriculture, Freshwater Fisheries Research Center, Chinese Academy of Fishery \\ Sciences, Wuxi 214081, China
}

Key words: channel catfish industry, development, market, prospect, China

\begin{abstract}
In 1984, the Fisheries Research Institute of Hubei Province first introduced channel catfish from the US to China. Since then, the production of China's channel catfish has undergone volatile changes. In 2003, as a substitute for Pangasius fillets from Vietnam, the export volume of channel catfish-processed products increased considerably. In recent years, the Chinese channel catfish industry has shifted from dependence on American and European markets to dominance in Chinese markets. It is expected that the continuing impact of the Covid-19 epidemic in China and the development of the global pandemic will significantly affect the channel catfish farming sector in China. This paper outlines China's channel catfish industry's development, markets, costs, and benefits and provides some suggestions for its development.
\end{abstract}

*Corresponding author: Yuan Yuan. e-mail: yuany@ffrc.cn

* These authors contributed equally to this work 


\section{Introduction}

Historically, channel catfish (Ictalurus punctatus) were the major catfish species in northern Mexico and southern Canada (Wang, 1988). Moreover, they are the most numerous aquaculture species in the United States (Michaletz and Dillard, 1999), with an annual production of 153,428 tonnes (1000kg is a tonne or metric Ton), accounting for more than $30 \%$ of the total aquaculture fishery production in 2019 (FAO, 2020). In 1984, the Fisheries Research Institute of Hubei Province first introduced Channel catfish from California to China (Cai et al., 1989; Cai et al., 1991a; Cai et al., 1991b; Zhou, 1986), and artificial reproduction was successfully carried out in 1987 (Chen, 1988). In recent years, channel catfish have played an essential role in specialty freshwater fish aquaculture in China due to a wide range of suitable farming areas, fast growth, large harvest size, and high quality (Tao, 2017). With the development of biology, ecology, breeding, and farming technology, channel catfish have been cultured on a large scale, becoming one of the top aquatic products. The rapid growth of channel catfish aquaculture has prompted a complete industrial chain, including seed supply, table fish production, processing, and export (Zhong et al., 2017). China and the US have become the biggest channel catfish producers and consumers. In what follows, we analyze the development of the channel catfish industry, its markets (exports and domestic markets), and its cost and benefits in China. Regarding the sustainable development of China's channel fish industry, problems with the industry and suggestions for its improvement are also discussed.

\section{Development of the channel catfish industry in China}

In 2019, six countries produced channel catfish, with a total production of 454,477 tonness. It increased $17 \%$ over the previous year, aquaculture production was 453,511 tonnes, and fishery production was a mere 996 tonnes (FAO, 2020). The countries that produce channel catfish are China, the US, Russia, Mexico, Italy, and Bulgaria. The US produces roughly a third of the world's channel catfish, while China produces nearly twothirds. Russia, Mexico, Italy, and Bulgaria together produce less than 1\%. From 2003 to 2007, global channel catfish production increased rapidly, with an average annual growth rate of $8.14 \%$. However, from 2008 to 2011 , production declined with a minimum volume of 355,031 tonnes in 2011. Production has steadily increased since 2012, with an average annual growth rate of $1.16 \%$ from 2012 to 2018 . The proportion of China's channel catfish production in the world has also increased. In 2003 , the proportion was only $11.48 \%$, and it rose to $48.54 \%$ in 2008 . Since 2011 , China's channel catfish production has accounted for more than $50 \%$ of the world's production, becoming the largest producer. In recent years, the proportion has stabilized at $60 \%$ (Figure 1).

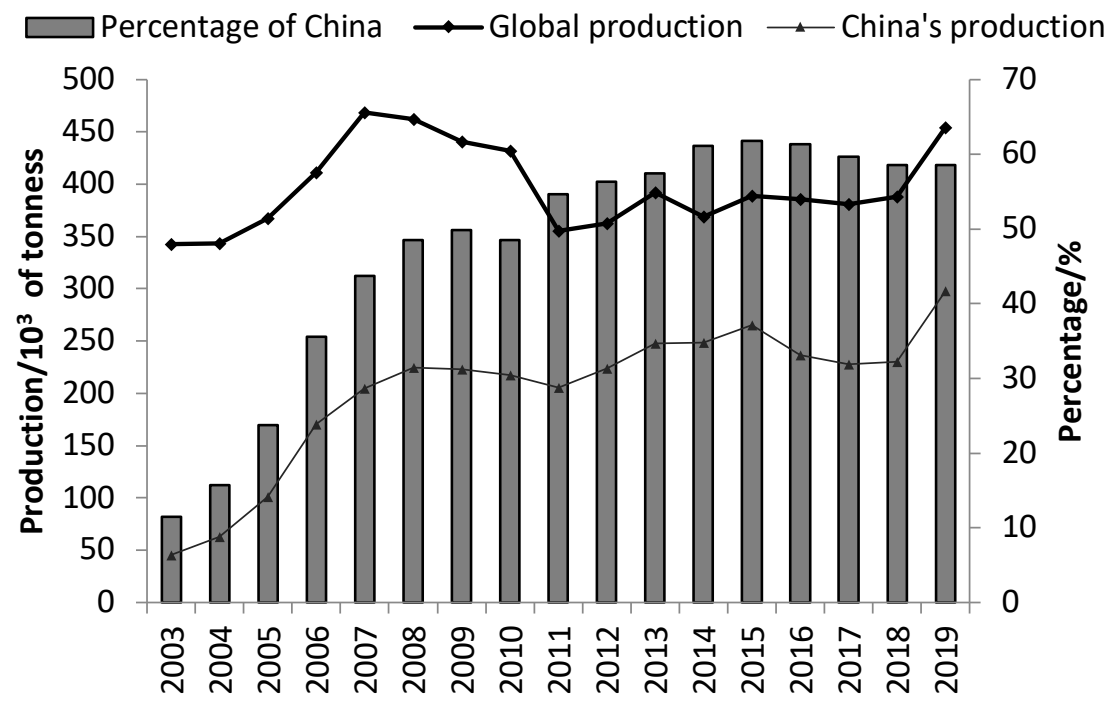

Figure 1 Channel catfish production globally and in China from 2003 to 2019. Data source: FAOSTATS, 2021

The Israeli Journal of Aquaculture - Bamidgeh • IJA.73.2021.1490779 
The development of the channel catfish industry in China can be divided into five periods:

Phase I (1984-1995): Since channel catfish were introduced in 1984, and artificial reproduction was successfully carried out in 1987; production showed a rapid spread in aquaculture in the initial stage. It spread from Hubei to Hunan, Guangdong, Guangxi, Jiangsu, Jiangxi, and Liaoning. Channel catfish were mainly cultivated in Hubei and Guangdong, with less than 10,000 tonnes of total annual yield. Live products were the main focus, with high prices due to low production ( $\mathrm{Li}$ and Gao, 2018). Compared with other types of fish, channel catfish production was too low to be included in official statistics. As such, China does not have accurate statistics on the production of channel catfish during this period.

Phase II (1996-2002): During this period, breeding, reproduction, cultivation technology, quality control, and marketing improved. As the expansion of farming grew and increased fish production, the channel catfish industry developed rapidly. By the end of the 1990s, China's annual yield of channel catfish reached approximately 50,000 tonnes (Zhong et al., 2016). With small quantities of processed products exported to the US, foreign market demand emerged. Meanwhile, the domestic market broadened.

Phase III (2003-2008): This period can be called the "industrialization phase" because channel catfish industrialization gradually matured and developed rapidly over this period. In 2003, as a substitute for Pangasius fillets from Vietnam, the processed products of channel catfish (frozen fish fillets) ushered in new opportunities because the US Department of Commerce imposed an anti-dumping tariff on Vietnam's Pangasius imports (USITC, 2003). As a result, processing plants spread across more than 20 provinces in China, including Jiangsu, Jiangxi, Hunan, Hubei, and Anhui (Qin et al., 2010). In 2008, the production of channel catfish reached 224,471 tonnes, with an export volume of 17,000 tonnes. Domestic market demand was not significant during this period, and the products were mainly exported to American and European markets.

Phase IV (2009-2015): During this period, foreign demand shifted to domestic demand. In 2006 and 2007, due to the impact of drug residues and traces of antibiotics in some tested channel fish samples in Alabama, Louisiana, and Mississippi (USITC, 2009; Terrill and Corey, 2007), exports of channel catfish from China to the US significantly reduced. Production in 2011 was $8.60 \%$ lower than in 2008. With the gradual expansion of the domestic market, the situation of channel catfish industry gradually improved. Since 2012, production has increased significantly. In 2015, it reached 264,965 tonnes, with an average annual growth rate of $5.74 \%$ from 2012 to 2015 .

Phase V (2016 to present): In 2016, the Chinese government issued new policies on environmental protection and banned caged aquaculture in reservoirs ( $\mathrm{Hu}$ and $\mathrm{Lv}$, 2016). Many unlicensed, illegally constructed, and substandard sewage disposal farms were closed. The sharp reduction of aquaculture regions directly led to a decline in the production of catfish farming. The production of channel catfish in 2016 was 236,786 tonnes, a decrease of $10.64 \%$ over the previous year. With adjustments in farming practices, the production of channel catfish began to increase gradually. In 2018, production increased by $1.31 \%$ compared with 2017 . In 2019 , production increased by $29.20 \%$ over the previous year, with 28 provinces and municipalities across the country cultivating channel catfish. The five provinces with the most significant yields were Sichuan (87,532 tonnes), Guangdong (46,941 tonnes), Hubei (41,419 tonnes), Hunan $(30,544$ tonnes), and Henan (26,646 tonnes), accounting for $29.40 \%, 15.77 \%, 13.91 \%, 10.26 \%$, and $8.95 \%$, respectively, of the total production.

\section{Channel catfish market in China}

In 2015, China's channel catfish industry shifted from foreign to domestic demand. However, China's channel catfish exports were restricted in recent years, and the export price fluctuated wildly. With the effective development of the domestic market, China's channel catfish market has stabilized. 


\section{Foreign market demand}

In 2008 , the export volume of channel catfish peaked at 17,000 tonnes. It represents an increase of $88.14 \%$ compared with the previous year. The volume then declined from 2009 to 2012, with an average annual growth rate of $-31.13 \%$. Since 2006 , the minimum export volume was 3825 tonnes in 2012. In 2013 and 2014, the export volume recovered to 8305 and 8314 tonnes, respectively. However, exports were restricted and declined by $34.95 \%$ in 2015 . From 2015 to 2019 , the export volume experienced a slow recovery and fluctuation. The export volume recovered to 6239 tonnes in 2019, with an export value of $\$ 35.86$ million US dollars (Figure 2).

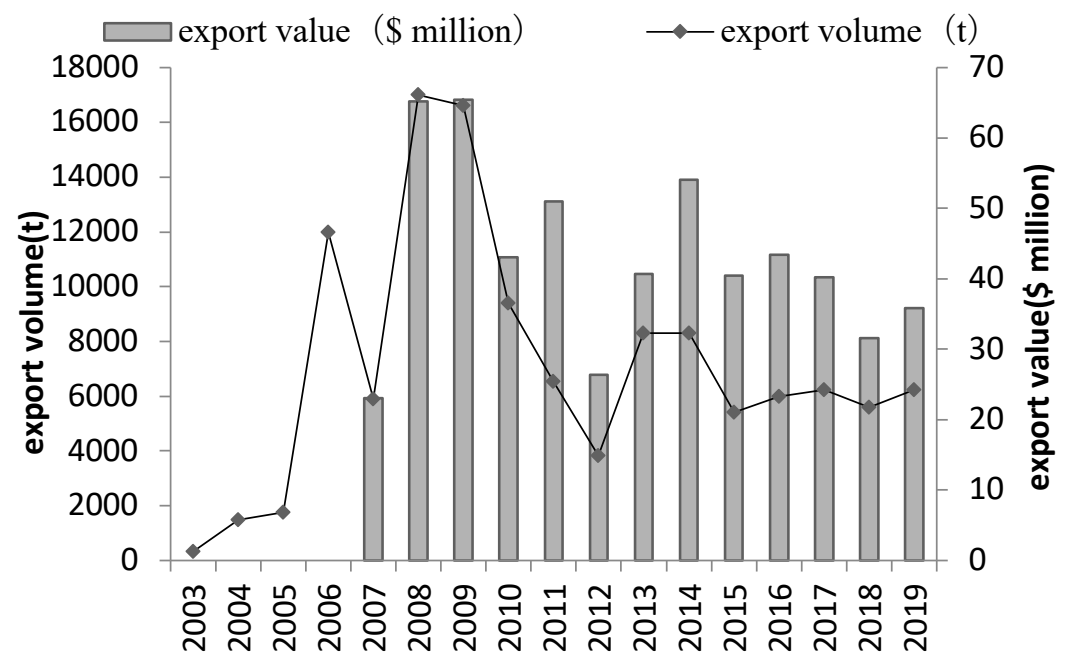

Figure 2 Channel catfish export volume and export value from 2003 to 2019.

Data source: Statistics of the Department of China Customs. Data on export values from 2003-2006 were not available.

In 2019, the top three export-targeted markets were the United States, the Democratic Republic of Congo, and the Republic of Congo. The United States accounted for more than $80 \%$ of China's total channel catfish exports, indicating that China's channel catfish depended heavily on the US market. Most exported products comprised prepared or preserved channel catfish, accounting for $70.73 \%$. The major producing and exporting provinces were Guangdong, Hubei, Anhui, Guangxi, and Jiangsu (Table 1). 
Table 1 Channel catfish export volume in 2019 (tonness)

\begin{tabular}{|c|c|c|c|c|c|}
\hline $\begin{array}{l}\text { Targeted- } \\
\text { markets }\end{array}$ & $\begin{array}{l}\text { Frozen } \\
\text { catfish } \\
\text { fillets }\end{array}$ & $\begin{array}{l}\text { Prepared or } \\
\text { preserved } \\
\text { Catfish, not } \\
\text { minced }\end{array}$ & $\begin{array}{l}\text { Export } \\
\text { Volume }\end{array}$ & $\begin{array}{l}\text { Exporting } \\
\text { provinces in } \\
\text { China }\end{array}$ & $\begin{array}{l}\text { Export } \\
\text { Volume }\end{array}$ \\
\hline $\begin{array}{l}\text { United } \\
\text { States }\end{array}$ & 1816.17 & 3210.71 & 5026.88 & Guangdong & 3843.27 \\
\hline $\begin{array}{l}\text { Democratic } \\
\text { Republic of } \\
\text { Congo }\end{array}$ & & 775.00 & 775.00 & Hubei & 884.18 \\
\hline $\begin{array}{l}\text { Republic of } \\
\text { Congo }\end{array}$ & & 178.00 & 178.00 & Anhui & 596.11 \\
\hline Cameroon & & 151.00 & 151.00 & Guangxi & 569.62 \\
\hline $\begin{array}{l}\text { Equatorial } \\
\text { Guinea }\end{array}$ & & 52.00 & 52.00 & Jiangsu & 346.08 \\
\hline $\begin{array}{l}\text { Central } \\
\text { Africa }\end{array}$ & & 24.72 & 24.72 & & \\
\hline Singapore & & 21.45 & 21.45 & & \\
\hline Tailand & 10.20 & & 10.20 & & \\
\hline Costa Rica & & 0.009 & 0.009 & & \\
\hline sum & 1826.37 & 4412.89 & 6239.26 & sum & 6239.26 \\
\hline
\end{tabular}

Data sources: Statistics of the Department of China Customs.

\section{Domestic market demand}

Since 2012, channel catfish have relied on domestic demand more than foreign market demand, which has gradually increased. According to customs statistics, exports of channel catfish reached 6239 tonnes in 2019 , a significant increase $(11.49 \%)$ compared with the previous year. Specifically, exports comprised 1826 tonnes of frozen catfish fillets and 4413 tonnes of prepared or preserved catfish. According to Xiao (2014), $2.50 \mathrm{~kg}$ of live fish are needed to process $1 \mathrm{~kg}$ of frozen catfish fillets, and $1.33 \mathrm{~kg}$ of live fish are needed for $1 \mathrm{~kg}$ of prepared or preserved catfish. Therefore, channel catfish exports consumed 10,435 tonnes of live fish in 2019 , accounting for $3.50 \%$ of the total national yield. On the other hand, domestic consumption was approximately 287,000 tonnes, accounting for the majority of the total national yield $(96.54 \%)$, as showed in Table 2.

Table 2 Channel catfish consumption in foreign and domestic markets in 2019 (tonness)

\begin{tabular}{ccccc|cc}
\hline & \multicolumn{3}{c|}{ Foreign market } & \multicolumn{2}{c}{ Domestic market } \\
\cline { 2 - 7 } Year & $\begin{array}{c}\text { Volume of } \\
\text { frozen } \\
\text { catfish } \\
\text { fillets }\end{array}$ & $\begin{array}{c}\text { Volume of } \\
\text { prepared or } \\
\text { preserved } \\
\text { catfish }\end{array}$ & $\begin{array}{c}\text { Live fish } \\
\text { consumption }\end{array}$ & $\begin{array}{c}\text { Percentage } \\
(\%)\end{array}$ & $\begin{array}{c}\text { Live fish } \\
\text { consumption }\end{array}$ & $\begin{array}{c}\text { Percentage } \\
(\%)\end{array}$ \\
\hline 2012 & 3626.16 & 198.42 & 9329.30 & $4.16 \%$ & 214802.70 & $95.84 \%$ \\
2013 & 7180.76 & 1124.22 & 19447.12 & $7.86 \%$ & 227951.88 & $92.14 \%$ \\
2014 & 7531.69 & 781.96 & 19869.24 & $7.99 \%$ & 228738.76 & $92.01 \%$ \\
2015 & 5035.70 & 372.04 & 13084.05 & $4.94 \%$ & 251880.95 & $95.06 \%$ \\
2016 & 5953.06 & 38.74 & 14934.18 & $6.31 \%$ & 221851.82 & $93.69 \%$ \\
2017 & 4501.30 & 1745.21 & 13574.38 & $5.97 \%$ & 213879.62 & $94.03 \%$ \\
2018 & 2157.49 & 3438.55 & 9967.00 & $4.33 \%$ & 220475.00 & $95.67 \%$ \\
2019 & 1826.37 & 4412.89 & 10435.069 & $3.50 \%$ & 287296.93 & $96.50 \%$ \\
\hline
\end{tabular}

Data sources: Statistics of the Department of China Customs; China Fishery Statistical Yearbook. 
At present, China's channel catfish industry primarily relies on domestic market demand. The major markets in China are Chengdu, Chongqing, and Guiyang in southwestern China, followed by Xi'an, Xining, Taiyuan, and Shijiazhuang in the north and west of China. There is also increased demand in metropolises such as Beijing, Shanghai, and Guangzhou, with the products of barbecued fish.

In recent years, the domestic market price of catfish in China is higher than that of similar species, which brought about a rapid increase in the scale of cultivation. However, limited market demand has caused a downturn in fish prices. In 2017, domestic and foreign markets dropped prices sharply, which showed a decreasing trend in the channel catfish industry. The centralized demolition of cages in 2017 greatly affected the price of channel catfish. Many table fish had to be listed on the market, resulting in sharp price reductions. In addition, Pangasius fillets from Vietnam were squeezing the domestic market share. These factors all caused the decline in the price of channel catfish in 2017. In 2018, the area of China's channel catfish cultured in cages decreased, which led to a decrease in supply and an increase in the price of table catfish. Prices in the first half of 2018 were slightly lower than in the same period in 2017 but higher in the second half-and the prices continued to rise. In 2019, along with an increase in supply, prices started to fall to levels much lower than in 2018, and the average price of channel catfish was about RMB ${ }^{1}$ $21.5 / \mathrm{kg}$, approximately US dollars $3.1 / \mathrm{kg}$ (Figure 3 ).

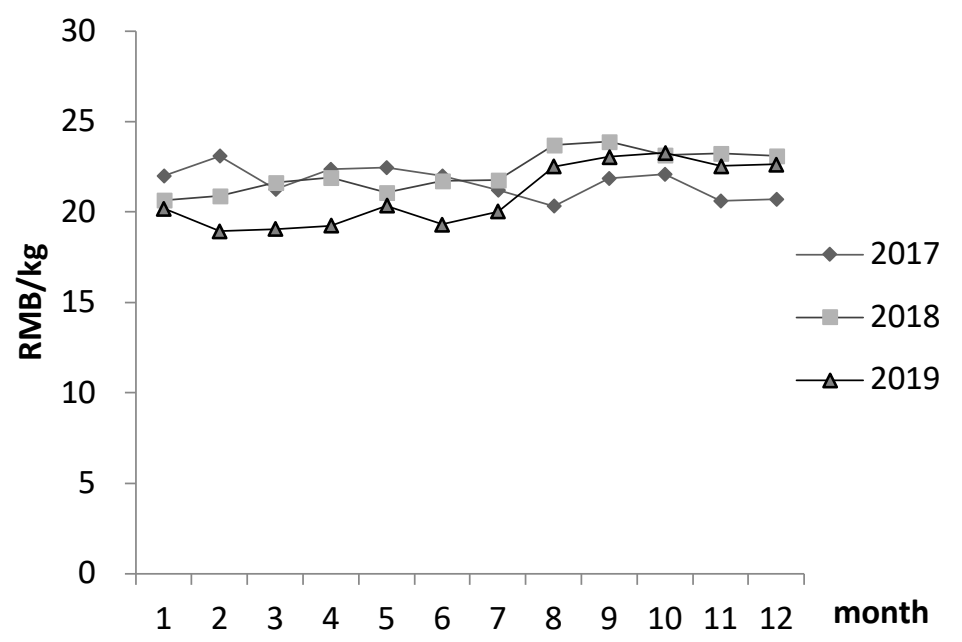

Figure 3 Gate price ${ }^{2}$ of fresh and live channel catfish from 2017 to 2019 (500 g s piece < $1000 \mathrm{~g}$. Data source: Economic Database of Freshwater Fish with Characteristics Industry Technology System (CARS 46).

\section{Cost of channel catfish}

\section{Cost-benefit analysis of channel catfish in China}

Channel catfish in China are mainly cultured in earthen ponds, like other freshwater fish species (Rola and Hasan, 2007; USDA/NASS, 2007). Feed, labor, seed, rent, medicine, water, and electricity are the high costs of farming channel catfish (Zhong et al., 2016).

In 2019, the cost of pond farming channel catfish was RMB $10.6-11.6 / \mathrm{kg}$, approximately US dollars $1.5-1.7 / \mathrm{kg}$ (including farming costs and losses from disease). Feed costs accounted for about $80 \%$ of the total cost, labor costs accounted for about $10 \%$, seed costs accounted for about $5 \%$, and rent, medicine, water, and electricity costs accounted for about $5 \%$.

\footnotetext{
${ }^{1}$ RMB is the legal currency of the People's Republic of China. RMB is abbreviation for Ren Min Bi, when loosely translated into English means People's Money / notes. Yuan is the base unit for RMB - just as Dollar in USD.
} 
The feed price in 2019 was about RMB 4400-5800/tonne (US dollars 638-841/kg), and the FCR (feed conversion ratio) was 1.6-1.9 on average (Filbrun et al., 2013). It is unsustainable to use the cultured methods with excessive additions of high-protein manufactured feed because the net yield of fish protein decreases with increased production intensification (Naylor et al., 2000; Dey et al., 2005). Labor costs around RMB $3000-5000 /$ month (US dollars $435-725 / \mathrm{kg}$ ), and a laborer can manage 1.3-2 hectares of fish ponds. The price of catfish fry changes with the price of table fish, but there is a lag period. In 2017, the price of channel catfish fry was about RMB 20/1000 tails (US dollars 2.9/1000 tails), and in 2018 it decreased to RMB 16/1000 tails (US dollars 2.3/1000 tails). In 2019, the price rose to RMB 30/1000 tails (US dollars 4.3/1000 tails). With the increase in the price of table fish in 2018, the seed price also gradually rose in 2019, and the demand for seed changed to the requirement for quality.

\section{Yield of channel catfish}

The unit yield of channel catfish varies significantly in different regions, typically between 6500 and $11,250 \mathrm{~kg} / \mathrm{hm}^{2}$. In 2019, the average gate price was RMB $21.5 / \mathrm{kg}$ (US dollars $3.1 / \mathrm{kg}$ ), and the annual output value was RMB 117,000 to $176,000 / \mathrm{hm}^{2}$ (US dollars $\left.16,960-25,512 / \mathrm{hm}^{2}\right)$. After deducting farming costs and losses from disease, the annual income was RMB $30,000-48,000 / \mathrm{hm}^{2}$ (US dollars $4,349-6,958 / \mathrm{hm}^{2}$ ).

\section{Prospects for the channel catfish industry in China}

In 2018, the gate price of channel catfish remained high, and domestic market demand continued to increase. In 2019, the price of channel catfish was relatively stable. Compared with other similar freshwater fish, channel catfish were much more expensive, and demand was relatively stable. Therefore, the cultured area will not increase much in the following years, and the price is expected to rise. It therefore, has prompted farmers to change from an extensive and disorderly cultured mode to a scientific mode. At present, channel catfish are mainly cultivated in ponds, containers, and factories, and channel catfish farming is gradually moving towards intensification and refinement.

With the strict enforcement of measures to contain Covid-19 in China, the epidemic was effectively controlled in China by late March 2020. The supply chain of the aquaculture sector recovered by April 2020. Farming operations gradually returned to normal, and processing factories resumed. Logistic systems related to aquaculture products and the trade and sale of live channel catfish also returned to normal. However, the impact of Covid-19 in China and around the world significantly affected the performance of the channel catfish farming sector in China.

According to predictions by the industrial experts, with the effective control of Covid19 , total fisheries production in 2020 will approximate 2019 levels, amounting to around 64.8 million tonnes. However, the evolving situation of the Covid-19 pandemic has had a significant impact on economies, resulting in low demand for aquatic foods in the international market. As a result, overall imports and exports of channel catfish of China are expected to decline. The effective development of the domestic market has provided another path for the sustainable development of the channel catfish industry. However, the increase in alternative aquatic products in China has slowed the demand for channel catfish. It is expected that there will not be a significant increase in market demand for the next few years. The increase in production will directly increase the market supply and cause an oversupply. Therefore, it is expected that the market price of catfish will decline.

\section{Problems and Suggestions}

China's catfish industry has shifted from relying on American and European markets to dominance by domestic markets. However, the channel catfish industry in China has changed in recent years and currently faces many problems, such as oversupply and competition from other similar species (Channel Catfish Branch of China Fisheries Association, 2014). Therefore, it is desirable to improve product quality, restructure supplies, and develop new products, to improve the market competitiveness of China's channel catfish. 
(1) Promote ecological aquaculture and reduce the occurrence of disease. The development of aquaculture is inseparable from the health and stability of the ecological environment. Therefore, in channel catfish farming, attention should be paid to improving the ecological environment, reducing disease, and promoting the health of the fish. Thus, healthy and sustainable channel catfish can be produced while maintaining the ecological balance in the aquaculture industry (Guo, 2010). In addition, improvements to product quality are a prerequisite for expansion in international and domestic markets; and promoting the development of China's channel catfish industry.

(2) Arrange a good supply to avoid market risks. The price of channel catfish fluctuates wildly. If farmers blindly arrange their production plans for the following year based on current prices, they will face added risk. There are two solutions to balance the supply and demand of China's channel catfish. The first is to develop vertically integrated companies that are market-oriented to control the total supply. Integrated cooperation between farmers and companies is rare in China, but this is an inevitable trend ( $\mathrm{Li}$ and Gao, 2018). The second solution is to establish regional agricultural cooperatives or associations that can help the government control the surface area and yield of channel fish within a suitable range.

(3) Encourage the development of new products to adapt to new market needs. Support should be offered to processing plants and farmers for developing new products, such as semi-cooked, ready-to-eat, and prepared fish dishes. Such products are more suitable for online sales and distant delivery, and they can replace live fish in conventional markets. In addition, diversified and convenient fish products of high nutritional value are desirable, as consumers pay more attention to health and food safety in the wake of the pandemic (Cohen, 2020). Finally, improvements are needed in packaging and safety standards for fish products to facilitate the transportation and storage of products and for diversified modes of marketing.

\section{Acknowledgements}

This study was supported by China Agriculture Research System of MOF and MARA (CARS46), and Wuxi City College of Vocational Technology Research Project (0660101024).

\section{References}

Cai, Y.Z., Tao, J.J., Ge, L., He, S.Q., 1991a. Observations on the embryonic and larval development of channel catfish. Journal of Fisheries. 15 (4): 308-316. (in Chinese)

Cai, Y.Z., Tao, J.J., Ge, L., He, S.Q., 1991b. Larvae cultivation technology of channel catfish. Reservoir Fisheries. 11 (3): 22-25. (in Chinese)

Cai, Y.Z., Tao, J.J., He, S.Q., Ge, L.,1989. Biological characteristics and cultivation technology of channel catfish. Freshwater Fisheries. 19 (4): 31-32. (in Chinese)

Cai, Z.H., Xing, K.Z., Guo, Y.J., 1998. Effects of several vitamins on fry of channel catfish. Journal of Tianjin Agricultural college. Coll. 5 (3): 6-9. (in Chinese)

Channel Catfish Branch of China Fisheries Association, 2014. Report of channel catfish Industry in China. Ocean and Fisheries. (11): 25-26. (in Chinese)

Chen, D.G., 1988. New varieties of fish-channel catfish (Ictalurus punctatus) and brown bullhead. Sichuan Agricultural Sciences. 6: 3434. (in Chinese)

Dey, M.M., Rab, M.A., Paraguas, F.J., Bhatta, R., Alam, M.F., Koeshendrajana, S., Ahmed, M., 2005. Status and economics of freshwater aquaculture in selected countries of Asia. Aquaculture Economics and Management 9: 11- 37. https://doi.org/10.1080/13657300590961609

FAO., 2020. The state of world fisheries and aquaculture. In: FAO of the United Nations [online]. Rome. Updated 2020. http://www.fao.org/3/ca9229en/ca9229en.pdf

Filbrun, J.E., Reynolds, C.A., Culver D.A., 2013. Effects of Feeding Rate on Habitat Quality in Fish Rearing Ponds. Journal of the World Aquaculture Society 44:2, 198-209. https://onlinelibrary.wiley.com/doi/epdf/10.1111/jwas.12018

Guo, Z.J., 2010. The development, challenges and countermeasures of channel catfish industry in China. China Fisheries. (12): 11-13. (in Chinese) 
Hu, Q.Y., Lv, J.L., 2016. Hubei promotes the removal of cages in rivers and lakes [EB/OL] http://www.hubei.gov.cn/hbfb/bmdt/201611/t20161111_1512354.shtml

Li, D.P., Gao, Y., 2018. Channel Catfish Culture: Success Stories and Modern Trends//in book: Aquaculture in China: 393-403. http://dx.doi.org/10.1002/9781119120759.ch4_3

Cohen, M.J., 2020. Does the COVID-19 outbreak mark the onset of a sustainable consumption transition? Sustainability: Science, Practice and Policy. 16(1): 1-3. https://doi.org/10.1080/15487733.2020.1740472

Michaletz, P. H., Dillard J. G., 1999. A survey of catfish management in the United States and Canada. Fisheries 24(8):6-11. https://doi.org/10.1577/15488446(1999)024<0006:ASOCMI > 2.0.CO;2

Naylor, R. L., Goldburg, R. J., Primavera, J. H., Kautsky, N., Beveridge, M.C.M., Clay, J., Folke, C., Lubchenco, J., Mooney, H., and Troel,I M., 2000. Effect of aquaculture on world fish supplies. Nature 405: 1017-1024.

Qin, Z.J., Yu, B.H., Qian, C., 2010. Effects and countermeasures of the new policy issued by the United States on the export of China's channel catfish industry. China Inspection and Quarantine, (5): 19-20. (in Chinese)

Rola, W. R., Hasan, M. R., 2007. Economics of aquaculture feeding practices: a synthesis of case studies undertaken in six Asian countries. Pages 1-31 in M. R. Hasan, editor. Economics of aquaculture feeding practices in selected Asian countries. Food and Agricultural Organization of the United Nations (FAO) Fisheries Technical Paper No. 505, Rome, Italy.

Tao, J.J.,2017. Summary of the development of the channel catfish industry. Fishery Rich Guide. 13: 14-17. (in Chinese)

Terrill, R.H., Corey, M., 2007. The 2007 farm bill: Policy options and consequencescatfish policy, Oak Brook, IL: National Public Policy Education Committee, Farm Foundation. Feb. 2007.

USDA/NASS (United States Department of Agriculture/National Agricultural Statistics Service), 2007. Census of aquaculture (2005). USDA/NASS, Washington, DC, USA.

USITC, 2003. Certain frozen Fish fillets from Vietnam injure U.S. industry, Says ITC. http://www.usitc.gov/press_room/news_release/2003/er0723aa2.htm (accessed 2003.07.23).

USITC, 2009. Certain Frozen Fish Fillets from Vietnam. Investigation No. 731-TA-1012 (Review).

Wang, Z.K., Liu, Y.P., He, H.Z., Lan, Z.Q., Wan, L.H., Wu, G.J., 1998. Utilization of Chinese herbal medicine fermentation feed for cage culture of channel catfish. China Fisheries. 42(2): 30-31. (in Chinese)

WHO, 2020. R\&D Blueprint and COVID-19 [EB/OL], 2020.04. https://www.who.int/teams/blueprint/covid-19

Xiao, Y.H., 2014. The report of channel catfish industry analysis in 2014. Oceans and Fisheries (Fisheries Frontiers). (9): 91-92. (in Chinese)

Zhong, L.Q., Song, C., Chen, X.H., Deng, W., Xiao, Y.H., Wang, M.H., Qin, Q. Luan, S., Kong, J., Bian, W.J., 2016. Channel catfish in China: Historical aspects, current status, and problems. Aquaculture. 465:367-373. http://dx.doi.org/10.1016/j. aquaculture.2016.09.032

Zhong, L.Q., Wang, M.H., Chen, X.H., Zhang, S.Y., Qin, Q., Jiang, H.C., Bian, W.J., 2017. Status of the world channel catfish industry I: The status and prospects of channel catfish industry in the United States. Journal of Aquaculture 38 (5): 1-5. (in Chinese)

Zhou, S.H., 1986. Aquaculture of channel catfish. Foreign Fisheries. 12 (1), 6-10. (in Chinese) 